\title{
Palestinian Chicago
}

\author{
Spatial Location, Historical Formation
}

The hub of Palestinian immigrant life before the suburban exodus of the 1990s was a southwest corridor stretching east and west from the intersection of South Kedzie Avenue and West $63^{\text {rd }}$ Street. Palestinians had settled on the North Side, too, principally between Montrose and Foster, Clark and Kimball, and Kedzie and Lawrence Avenues (Cainkar 1988, 115-16). These individuals and families lived in ethnically heterogeneous neighborhoods. The Southwest Side corridor, by contrast, was a larger, more homogenous concentration than the North Side communities. It also hosted three community centers during the 1970 and 1980 os. These centers anchored group life for Palestinians across the city prior to the suburban shift at the turn of the millennium.

Members of the immigrant community citywide sold goods door-to-door, worked in factories, and owned small businesses-corner groceries, dry goods stores, gas stations, restaurants, and check-cashing operations. On the South Side, the businesses served the immigrants but also, increasingly, the larger surrounding African American and Latinx communities. After their move to the suburbs, Palestinian business owners commuted to their stores on the Southwest Side. At the end of the day, owners gated and padlocked their storefronts and drove back to the suburbs. ${ }^{1}$ In this daily traversal, they enacted a longstanding, intermediary social relation: Palestinians in Chicago had inserted themselves between the white ethnics who had also migrated to the suburbs and the working-class and poor black and immigrant Latinx who had moved into the neighborhoods the whites had vacated. The Southwest Side Palestinians would follow the whites but live apart from them within a borderland separating the brown and black city from the expanse of white suburbia. The Palestinian exile in Chicago was, in this way, a particular kind of experience inflected by the city's racial and economic segregation. 
This chapter describes this experience in detail. The discussion begins with the period of early migration in the late nineteenth century, during which Palestinians established their interstitial position between black and white residential and business zones. It then continues with developments through the wars of 1948 and 1967-a period crucial to the shift from "bimodal" migration patterns to permanent residency. The final sections of the chapter detail the organizations that have anchored the secular nationalist spaces of the Southwest Side enclave and, later, the new, Islamizing suburban community. In connection with this latter shift, the discussion also addresses the development of key Christian institutions.

\section{EARLY MIGRATION FROM PALESTINE: 1890s-1940s}

Palestinian migration to the United States dates to the 1890 . During this period, Chicago became a financial and industrial center, and its population boomed. Between 1860 and 1870 the city's residents tripled in number from 109,000 to 300,000; by 1890, the total had jumped to 1.1 million (Abu-Lughod 1999, 115-16). Foreign migration fueled this explosion. By 1900, nearly four out of five Chicagoans were either foreign-born or children of those individuals (116). The migrants came to work in the burgeoning steel and meatpacking industries. "Manufacturing establishments" went from approximately 3,500 in 1880 "to more than 10,000 " in 1919 (117). Owners sited their factories along the rail lines and canals away from the Loop-and beyond municipal regulation and taxation. Worker settlements grew up around the plants. In some cases, as with the Pullman factory or U.S. Steel in Gary, Indiana, owners built company towns (Buder 1967; Mayer and Wade 1969, 188-92; Carl Smith 1995, 177-231). These settlements distanced the nascent proletariat from the wealthy downtown and became zones of white ethnic segregation.

African American migration from the southern states also intensified. Between 1900 and 1930, the city's black population skyrocketed from approximately 30,000 to nearly 234,000 (Abu-Lughod 1999, 124). Having few other options, these migrants settled within an area soon to be called "the Black Belt." This South Side zone stretched along State Street between $12^{\text {th }}$ and $39^{\text {th }}$ Streets (Philpott 1991, 116 and elsewhere; Drake and Cayton 1993 [1945], 174 and elsewhere; Abu-Lughod 1999, 124-26). ${ }^{2}$ Surrounded by railroad track, a quarter mile wide, and three miles long, it became a densely populated and immiserated space (Philpott 1991, 117 and elsewhere; Drake and Cayton 1993 [1945], 198 and elsewhere; Abu-Lughod 1999, 122-25). ${ }^{3}$ Housing covenants and white vigilante violence enforced the segregation. During a race riot in 1919, white gangs marauded through the Black Belt. The Illinois National Guard restored order only after twenty-three blacks and fifteen whites had died (Abu-Lughod 1999, 126-27; Bates 2019). The violence foreshadowed the "border wars" that flared during the 1950s and 1960s as blacks moved into formerly all-white areas (Chicago Commission on Race Relations 1922; 
Philpott 1991, 120 and elsewhere; Drake and Cayton 1993 [1945], 198 and elsewhere; 1999, 124-27).

The Palestinian trajectories that intersected with these seismic and violent processes had their origins in socioeconomic shifts occurring in Greater Syria (inclusive of present-day Syria, Lebanon, and Palestine). Between 1899 and 1921, approximately 100,000 Syrians were allowed into the United States. Of this total, fewer than 6 percent were from the Jerusalem and Ramallah regions (Cainkar 1988, 68; Cainkar 1998; Serhan 2009, 12). The Chicago immigrants came mostly from these areas. Initially, most of these individuals were Christians from Ramallah; increasingly, however, Christian and Muslim peasants, who often lived together in mixed villages, began to migrate (Cainkar 1988 70-71; Serhan 2009, 15). This early migration was a direct outcome of Greater Syria's integration into a global market economy. European, especially French, naval and commercial expansion into the eastern Mediterranean during the seventeenth century initiated this process. The existing commercial classes in the Levant (present-day Syria, Palestine, Jordan, Lebanon) took advantage of newly lucrative opportunities for trade with the European states. In the process, they acquired capital that facilitated concentration of landholdings, introduction of new technology, and cultivation of cash crops such as oranges. These same elites sent their sons to study in European universities to gain new technocratic skills. Upon returning, this generation served in the commercial concerns of their families and in the new bureaucracies. They also led a host of new political movements. Some of these movements agitated for the enfranchisement of Ottoman subjects-Muslims, Christians and Jews-as citizens. ${ }^{4}$

The Ottoman authorities responded to these developments by instituting legal reforms that intensified the already existing divisions between the landed and commercial elites and the former peasants-turned-sharecroppers. The Land Code of 1858, for example, enabled absentee landlords and foreigners (through an amendment in 1867) to gain legal title to uncultivated expanses. It also broke up collectively owned fields-for example, the musha' system through which villages held land in common-into individually titled holdings. Village notables often signed legal titles on behalf of peasants, acquiring control of these lands in their own right. Absentee owners in the cities also gained control of large estates through the new legal mechanisms. And finally, the reforms opened the door to the acquisition of contiguous holdings by the nascent Zionist movement. These holdings would become the foundation for the Yishuv (Jewish settlement), which emphasized Jewish labor to the exclusion of Palestinian (Muslim and Christian) agriculturalists (Krämer 2008, 71-100). These changes in land ownership rendered sharecropping increasingly difficult. In response, young men began to abandon the villages in search of employment in new industrial hubs like Haifa and, much further afield, Chicago. Steamship company propaganda was an especially important spur to foreign migration. 
The young men who migrated abroad to cities like Chicago had no intention of settling permanently in the United States. Instead, they established a bimodal pattern of residency and work: after several years, the men would return to their villages, build a house, pursue marriage, and then return again, alone, to continue work in the United States. This alternation counteracted assimilation by reinforcing family bonds "back home" and underscoring the instrumental purpose and impermanent nature of residency in the mahjar (literally, the place of sojourn, that is, the diaspora) (Oschinsky 1947, 23-24; Cainkar 1988, 73).

The temporary, pragmatic character of Palestinian migration manifested in the non-permanent nature of Palestinian settlement and work. The earliest immigrants did not purchase or build homes but rather rented rooms in boarding houses situated on the edge of the Black Belt. By 1912 some 150 mostly young Arab men lived in such houses in the Michigan Avenue and 18th Street area (Oschinsky 1947, 23). Within these spaces, they formed "an exclusively male community of peddlers" whose intention was to acquire wealth and return to their villages (Cainkar 1988, 74, paraphrasing al-Tahir 1952).

The First World War rendered returning hazardous, however: sea passage became dangerous and the fighting between Axis and Allied forces disrupted life in the migrants' home communities. In response, the men suspended their return visits and remained in Chicago. As their peddling capital accumulated, they began to buy small shops. One of Oschinsky's (1947) informants described peddling door-to-door with his uncle on the West Side. By 1923, he had saved enough money to start a dry goods store of his own on 18th Street (24). Between 1920 and 1935, Palestinian merchants opened numerous small stores in and along the edge of the Black Belt (23-24).

Within this "transition zone," Palestinian storeowners catered primarily to an African American clientele. In doing so, they became a "middle minority" or "stranger" group straddling the racial divide between blacks and whites (Cainkar 1988, 101-2). Although most stores employed one or two African American saleswomen, the relationship with the black community could sometimes be tense and marked by stereotyped attitudes and even open conflict (Oschinsky 1947, 24-26; al-Tahir 1952, 122). One of Oschinsky's interlocutors, for example, recounted in detail how he became a target of robberies and how he violently confronted intruders in his premises after hours. He and other individuals with whom Oschinsky interacted expressed racialized views of their African American customers in describing such situations (25-26). ${ }^{6}$ Intercommunal tensions of this sort persisted through the decades and have continued into the present (Blackistone 1981; Blackistone and Corrigan 1986; Robles 1989; Brachear 2010; Moore 2012). ${ }^{7}$

At the same time, however, shop owner-clientele interactions have not always been negative. Oschinsky $(1947,26)$ observed that the frequency of conflicts did not seem as high as his informants had indicated and that anyway Islam did not 
condone racism. And, although he reported bigoted attitudes among his Palestinian interlocutors, al-Tahir $(1952,193)$ claimed later in the same study that there was no class or racial tension between the communities. ${ }^{8}$ He cited the example of how the Arab Club - an organization created by immigrants from Beitunia-held occasional meetings in the "Negro Muslim Temple," a Nation of Islam worship space at 824 East 43rd Street. ${ }^{9}$ The club, al-Tahir stated, had plans to hold lectures there on Arabic language and Islamic history. This interaction seemed to indicate a desire for mutual understanding and social interaction. Al-Tahir argued that a shared commitment to Islamic ideals of equality enabled these positive relationships (al-Tahir 1952, 193). ${ }^{10}$ Shop owner-clientele relationships could also sometimes lead to Palestinian integration into the community, for example, through intermarriage (Moore 2012). As well, various Palestinian and Muslim organizations forged alliances with African American activist groups during the height of decolonization and the Third World movement. Most recently these connections have manifested in black-Palestinian solidarity in the face of police violence in African American communities and Israel's bombardments of the Gaza Strip (Erakat 2018). During the past two decades, too, Palestinian and Muslim activists have sought to address the tensions between shop owners and their South Side clientele through campaigns to encourage stores to stock fresh produce and to cease the sale of liquor and lottery tickets (Brachear 2010; Freedman 2014).

Unlike the predominantly Muslim Palestinians in Chicago, other Arab immigrants-primarily Christians from current-day Lebanon and Syria who constituted the vast majority of the early waves of Arab immigrants-desired to remain in the United States permanently (Gualtieri 2009, 45-53 and elsewhere; al-Tahir 1952, 70-71). Beginning in 1909, these immigrants waged a sustained effort in the courts to count as "Caucasian" - a requirement for citizenship at the time. One of their key arguments was that the Middle East, the Levant region in particular, was the cradle of Christianity and for that reason was linked inextricably to Europe (Gualtieri 2009, 56-57). After a number of contradictory lower court decisions, a federal judge determined in Dow v. United States (1915) that Syrians, as Arab immigrants were then called, "were so related to their neighbors on the European side of the Mediterranean that they should be classed as white" according to the original intent of the 1790 statute governing immigration (74). In the wider society, especially in the South, however, they could sometimes be viewed racially as black, as the lynching of Nola Romey in Lake City, Florida, in 1929 symbolically attested (Gualtieri 2009, 114-34). Thus, even if they had won the legal right to citizenship, Arab immigrants, including Palestinians in Chicago, remained situated in a culturally ambiguous zone in which their social status could shift, at times violently.

The life of early-wave Palestinian immigrants revolved principally around the norms of work. The men kept long hours, remaining behind their counters for 
twelve hours a day and longer on Saturdays (Oschinsky 1947, 26). Many cooked and slept in the rear areas of their stores. After closing their shops, they played cards and backgammon late into the night at Arab-owned coffee houses and restaurants such as Mecca, Arabian Nights, and Scheherazade, which were situated along Michigan Avenue between 22nd and 45th Streets (Oschinsky 1947, 26; al-Tahir 1952, 78, 95). On Saturday nights, they went to the movies; some went to bars to drink despite the Islamic prohibition on alcohol (Oschinsky 1947, 26). Once a month, they met on Sunday to discuss the intensifying conflict between Palestinians and the Zionist movement (Oschinsky 1947, 26; al-Tahir 1952, 78 and elsewhere on Palestinian nationalist sentiment). Oschinsky noted that shopkeepers earned between $\$ 5,000$ and $\$ 15,000$ per year, an amount that seemed extraordinary to the men and that perhaps enabled a few of them to afford cars (26). The temptations to spend hard-earned income and ignore morality concerned some members of the community. Oschinsky described "an old pious member" of the group, who complained that his fellow merchants had lost sight of religion (29). They didn't pray, he said, and they had forgotten the shahada (the statement of God's unity and Muhammad's messenger status), drank alcohol, and ate pork. They also, he claimed, had affairs with their customers or with Jewish and Christian women.

Generally, however, the men Oschinsky interacted with travelled to their villages to get married and then returned to Chicago alone to continue earning money. They remained in Chicago for five to ten years or longer and then went back to their families in Palestine before again leaving for the United States. Other men traveled between Chicago and their villages every six months. A few, however, brought their wives and children with them to Chicago. A handful had "taken common law American wives of Polish, Mexican, Irish, Italian, and Jewish origin [ . . . ]. One was married to a Syrian Christian" (Oschinsky 1947, 27). ${ }^{11}$ Most, though, were young and single and anticipated returning to Palestine. Relatives expected them to return with their wealth. Failure to do so was dishonorable. Repatriation, economic and personal, was a deeply felt obligation that stemmed assimilation.

This felt obligation was also, for some men, a religious one. As one individual put it, "It is very hard to be a good man in this bad land," where one could never be sure if one's eggs had been fried "in the grease of the khanzir (swine)" (bacon fat) and closing shop during Ramadan was potentially fatal to one's business success (Oschinsky 1947, 34). But return also brought ambivalence. One man described how after he had traveled home to get married other villagers accused him of being "stuck up," an "American," and a "city man." Another man reported that while he missed the clean air, fresh produce, and food of his village, life in Chicago provided freedom from family pressures and the chance to succeed if one worked hard (29-30). Such attractions, inevitably tinged with feelings of uncertainty, 
continued to draw Palestinians to the city. As the 1940s came to a close, however, political upheaval "back home" would add a further impetus for migration.

\section{MIGRATION, 1948-1967: TRANSFORMATIONS OF THE EXILIC SPACE}

The war of 1948 forced approximately 750,000 Palestinians into statelessness. The duration and extent of the violence transformed the migration calculus and bimodal migration pattern of the West Bank men who had established businesses in Chicago. The men and their families felt increasingly unsure that "home" would remain stable. Between 1936 and 1938 fewer than one hundred Palestinians arrived in Chicago (Zaghel 1976, 12); by contrast, between 1948 and 1967, the immigration rate to the United States averaged 660 individuals per year (Cainkar 1988, 74-77 and 81). Wives, children, and extended family members of already-established migrants constituted the majority of the new arrivals (Cainkar 1988, 81-86). Possessing Jordanian passports-Jordan had annexed the West Bank and East Jerusalem after the war of 1948 - many of these individuals, using family networks, came to Chicago. By 1950, more than five hundred Palestinians had established residency in the city (Zaghel 1976, 12).

In an extended interview, Imm 'Umar (pseudonym), a sixty-five-year-old resident of southwest suburban Bridgeview, recounted how these changes affected her parents. ${ }^{12}$ Versions of this story recurred frequently in interviews with those whose families had been in Chicago the longest. She described how her father had arrived in Chicago in 1939 immediately after the end of the 1936-39 Arab revolt. His uncle, who had already established himself in the city, helped him begin work as a peddler. He did not speak English and had never lived in a major metropolitan center "but he survived!" He returned to his village (Beitunia) to marry Imm 'Umar's mother in 1947. Her mother remained behind to give birth to her first child and then immigrated to Chicago through Beirut immediately following the end of the 1948 war.

Imm 'Umar's description of the experience of her parents emphasized the crucial importance of the pre-existing family networks - the "migration chain" - that had institutionalized migration as a strategy for economic advancement and wartime survival. These networks facilitated the arrival of Imm 'Umar's father and his subsequent initiation into the practices of peddling and Palestinian settlement. His decision to bring his wife and baby introduced a variation of these practices. Palestinians now began to maintain families in the city and thereby significantly alter the bimodal migration pattern. Palestinian residential locations also shifted. After 1948, immigrants began to settle further to the south and west of the city. Gradually, an enclave began to form in the Chicago Lawn, Marquette Park, and Gage Park areas. This location buffered the African American West Englewood neighborhood from the predominantly white West Lawn one (Figure 5). 


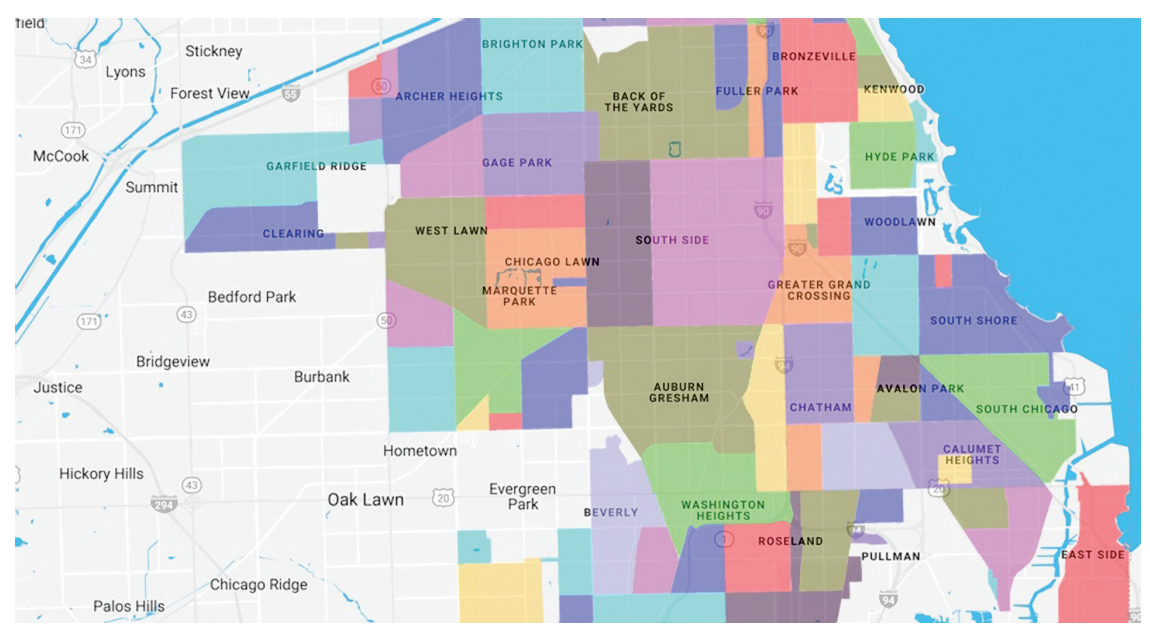

FIGURE 5. Chicago Community Areas Map. Courtesy of Peter Fitzgerald.

In situating themselves in this manner, Palestinians reprised their role as an interstitial "stranger" group. Individuals like Imm 'Umar's father still peddled, but families opened small stores on main thoroughfares such as West 63rd Street as they accumulated capital. These stores catered mostly to the growing Palestinian enclave but also to African Americans and Latinx communities that were becoming the majority of residents in the same area. ${ }^{13}$

Most of the Palestinian immigrants in the post-1948 period were Muslims. The preponderance came from one village-Beitunia-in the Ramallah area. A small group of Christians from the town of Ramallah, however, also migrated to Chicago. By 1946, just two years before the war of 1948, some 1,500 Ramallah Christians, roughly one-fifth of the town's Christian population, had immigrated to the United States (Zaghel 1976, 39-40). Of this total, forty individuals had migrated to Chicago (39). Within two decades this number would increase to 350 (44). Like the Beitunians, the Ramallahites peddled and then opened small grocery and linen stores. Some also worked in factories (39-52). Still, despite their shared class positions and common work practices, the Muslims and Christians lived in separate neighborhoods and congregated in separate institutional spaces (al-Tahir 1952, 67-68, 71, 93-98). In doing so, they replicated West Bank residence patterns in which they lived side-by-side, separately and symbiotically, in the same village or town (Neuhaus 1991; Tsimhoni 1993; Bowman 1993, 2001; Lybarger 2007b; Kårtveit 2014; Calder 2017).

As in the West Bank, the two segments of the community reinforced sectarian-communal separation through endogamy. Christians married Christians and Muslim married Muslims. Within these patterns, moreover, families sought 
to constrain marriage within kinship groupings organized along patrilocal lines and within place-specific affiliations. If one was from Ramallah, for example, one sought to marry a Ramallahite (Christian) from a particular family. Town/ village-based associations or clubs strengthened the sectarian, familial, and localeoriented solidarities that endogamy generated and relied on. The clubs not only provided spaces for leisure but also reconstituted communal ties; instilled these ties among youth, many of whom had never been to the home communities; introduced children to marriage partners; and maintained financial remittance channels to "back home."

One such club was the Children of Beitunia Club, organized in 1924. Its founding reflected an early desire to retain a placed-based affiliation and identity, resist assimilation, and facilitate the pooling of immigrant resources to support the village as a whole. The club renamed itself the "Arab Club" in the aftermath of the war of 1948. The renaming reflected a growing nationalist, pan-Arab sensibility. Club members soon formed three related organizations: the Arab Progress Club, Arab-American Aid Society, and Arab-American Women's Club, none of which now exists. The goals of these various organizations included teaching children Arabic and "Islamic values"; passing on "heritage" to youth; organizing support for the Palestinian cause; providing aid for refugees forced off their lands during the war of 1948; and funding projects in Beitunia (al-Tahir 1952, 105, 107-8). The financial assistance to the village was often substantial. During the early 1950s, the Arab Club sent \$20,000 to Beitunia to build an elementary school (105).

US-based Ramallahites established their own locale-focused organization, the Ramallah Club. The Chicago chapter was organized in 1957. Like its Beitunian counterpart, the Ramallah Club promoted opportunities to socialize, meet marriage partners, and contribute financially to projects in Ramallah itself. A primary goal of the club was to resist assimilation. A club leader stated, for example, that "the objectives of the organization are: (1) to help each other here, (2) not to melt in [sic] the American society, but to preserve our heritage and (3) to help Ramallah people back home" (Zaghel 1976, 49). Toward those ends, the club held annual Christmas parties and summer picnics, at which members participated in dabka dancing together and introduced young people to one another (49-52). The performance of dabka signified the nationalist orientation of the Ramallah club. Dabka, along with the checkered hatta scarf and embroidered thawb (pl. thiyab) dress, became a marker of "heritage" (turath) and national patrimony. They were and have remained central to the symbolic repertoire of the Arab nationalist and Palestinian liberation movements that first emerged during the 1950 and 1960 s.

The creation of the village and town clubs signaled the primacy of place, clan (hamula), social class (village peasants/fallahi versus town-dwellers/madani), and religious communalism (Christian or Muslim) in the identities of the early immigrants. ${ }^{14}$ The clubs reconstructed and reinforced these axes of affiliation in the 
diaspora. By contrast, formal religious organizations were relatively absent in both segments of the community. According to several participants in my research, Christians relied on itinerant priests based in Michigan City, Indiana, and Spring Valley, Illinois, to perform life-passage rites such as baptisms, marriages, and funerals. Some families, Melkite Catholic and Antiochian Orthodox, attended liturgies at the combined Melkite and Maronite Church of St. John the Baptist on South Washtenaw Street. Members subsequently transplanted this church to the northwest suburb of Northlake, Illinois.

Antiochian Orthodox Christians, who constituted the majority of Palestinian Christians, began to coalesce as an identifiable group by the late 1950s. Several families met on Sundays in the Syrian-Lebanese Club in the Austin neighborhood on Chicago's West Side. Orthodox priests travelled from Buffalo, New York, to serve the community. Imm George (pseudonym), an octogenarian, recounted how eventually, as the community grew, the Orthodox bishop in Pennsylvania appointed a full-time priest to lead the group. They also leased a former Episcopalian church in the Chicago suburb of Oak Park before ultimately moving into their current permanent premises in the town of Cicero. Imm George recounted further how the church community provided a space for newly arrived immigrants like her. Soon after arriving in Chicago, her husband took her to the church, where parishioners welcomed her with flowers and food. "It was amazing!" she said.

As Imm George indicated, the early phases of Antiochian Orthodox institutionalization occurred informally and entailed interaction with a wider Arab Christian community as well as with the national Orthodox Church. Increasingly, as Palestinian Christian immigration grew during the 1960s, and especially after 1967, religious institutionalization became formalized with the purchase of a worship space in Oak Park and the hiring of a full-time priest. ${ }^{15}$ That church and the subsequent one in Cicero-the St. George Antiochian Orthodox Churchbecame focal points of community life, providing, as well, important mechanisms of integration for new immigrants such as Imm George. The community was predominantly Palestinian but retained a pan-Orthodox character, attracting other Arab Christians as well as Orthodox practitioners from a variety of Southern and Eastern European backgrounds. ${ }^{16}$

A similar process of institutionalization also eventually occurred among Palestinian Muslims. In the earlier period, during the 1940s, however, religious practice remained individualized and ad hoc. Oschinsky (1947) observed that although some of the men with whom he interacted observed basic piety-the five prayers, abstention from pork and alcohol, fasting during Ramadan, and so on-many did not. Oschinsky noted that during Ramadan, for example, which fell during August 1946, the year he did his fieldwork, most of his interlocutors kept their shops open and ate at non-Arab restaurants, avoiding the coffee shops whose pious owners would not serve any food: "Not more than ten men kept the fast" $(33-34)$. The necessity to sustain their businesses appeared to supersede the required ritual duties. 
Less than a decade later, al-Tahir (1952) confirmed Oschinsky's observation concerning the lack of religious institutionalization and the low assiduousness of individual practice. He observed that the older generation had failed to maintain the fard (mandatory) rituals and had not instilled piety in their children $(58,151-52)$. The absence of mosques compounded the phenomenon. Nevertheless, although religious institutionalization remained weak, most Muslim immigrants still professed loyalty to Islam (173, and 207). One of the participants in my research recalled that during the 1950 os Muslim Palestinians rented out banquet halls or YMCA rooms to celebrate the annual feasts marking the Muslim religious calendar. Eventually, a group began to collect money to build a small mosque (al-Tahir 1952, 207). Similar efforts would occur later, ultimately resulting, in the late 1970s and early 1980s, in the construction of the Mosque Foundation, the dominant organization within the suburban Palestinian enclave today. Prior to this occurrence, however, Islam did not constitute the primary framework of group solidarity. Rather, in the immediate wake of the war of 1967 , nationalism began to galvanize identity within and across the Muslim and Christian segments of the community. Religious institutionalization did proceed, but during the first two and a half decades after the war, community life revolved around the cultural centers, locale-based clubs, and charitable foundations where a multisectarian secular nationalism took root.

THE NEW IMMIGRANTS AND

"RE-PALESTINIANIZATION": 1967-1980s

The war of 1967 marked a significant shift in the size, composition, ethos, and cohesion of the Palestinian immigrant community in Chicago. The war occurred two years after the Immigration and Nationality Act of 1965 abolished the nation-oforigin quotas in effect since 1921. The new law determined immigration eligibility according to preferred skills or relationship to US citizens or residents. Arabs, along with groups that had been excluded from citizenship as non-Europeans, now had expanded access to US immigration. The liberalization of the laws, and the increasing trend of seeking permanent residence rather than pursuing the bimodal migration pattern, however, did not shift the ambivalent, interstitial nature of Palestinian life in Chicago. Anti-Arab racism and government actions targeting community activists were the main reasons for the continuing ambivalence. With each successive Middle East crisis, Arabs, and especially Palestinians, found themselves positioned as a distinct, threatening presence within US society.

Zaghel (1976) documented this phenomenon, noting the sharp backlash against Arabs in local Chicago and national media in the immediate aftermath of the wars of 1967 and 1973 (187 and elsewhere in chapters 5 and 6). Cainkar (1988), too, emphasized that law enforcement interventions and anti-Arab racism heightened Palestinian feelings of estrangement from the wider culture. She cited the case of 
the LA Eight (132-33). In 1987, the FBI arrested eight individuals in Los Angeles that it accused of having ties with the Popular Front for the Liberation of Palestine. The subsequent twenty-year effort to convict the men failed (Goodman 2007). The revelation, during this imbroglio, of the Immigration and Naturalization Services memorandum Alien Terrorists and Undesirables: A Contingency Plan, 1986, confirmed the perception of many immigrants that US society was hostile to them (Cainkar 1988, 131-32; Wofford 2016). The plan proposed placing legal resident aliens from eight Arab countries in concentration camps. ${ }^{17}$ Additionally, in the mid-1980s Congress passed a bill to close the PLO's United Nations Observer Mission in New York. Intensified law enforcement intrusion and media stereotyping targeting Arabs and Muslims occurred, as well, in the aftermath of the bombing of the Alfred P. Murrah Federal Building in Oklahoma City in 1995 and also following the attacks of September 11, 2001. The cumulative effects of these measures and negative media coverage, beginning in 1967 , produced a cross-generational feeling of alienation among Palestinian immigrants. This alienation transformed the sojourner and stranger ethos that had defined community identity from its earliest moments into a collective sense of exile (Cainkar 1988, 96; Jamal and Naber 2008).

A renewed identification with Arabness reinforced this shift. Al-Tahir (1952, 105-8) observed that attachment to pan-Arab identity had formed among the early Arab immigrants during and after the First World War. During the 1930s and 1940s, Palestinians expressed strong sympathy for the struggle against Zionism and for the plight of refugees. The war of 1967 renewed this nationalist solidarity. The arrival of new immigrants from Palestine and the formation of nationalist community organizations institutionalized it (Oschinsky 1947, 31-32, 36-43; Zaghel 1976, chapters 5 and 6; Cainkar 1988, 110).

As in 1948, the war of 1967 resulted in a mass forced exodus of Palestinians, this time approximately 250,000 , from areas newly occupied by the Israeli military. ${ }^{18}$ These areas included the West Bank, which previously had been under Jordanian control. Prior to 1967, emigration from the West Bank amounted to approximately 3 percent of the population and entailed mostly movement from the West to the East Bank of Jordan. After the war, the migration rate jumped to 20 percent of the West Bank populace: skilled labor went mostly to the Arabian Gulf states and less skilled workers headed to various South American destinations and to the United States. More than 50 percent of the emigrants were women and children (Serhan 2009, 83).

Two forces impelled the new migration: the onerous conditions of Israeli military rule and the Israeli expropriation of Palestinian land to create Jewish-only settlements (Cainkar 1988, 92 and elsewhere; Cainkar 1998). ${ }^{19}$ Those with financial assets and transferable professional credentials were the most likely to leave. Preexisting family networks or "chains" also proved crucial. Prior to coming to the United States, "chain immigrants" had benefited from the financial remittances of 
their relatives. These remittances allowed their beneficiaries in Palestine to build new homes in areas that became known locally as "the American quarter." An important consequence of this phenomenon was an orientation toward the United States and the possibilities it presented for alternative life chances (Lutfiyya 1966, cited in Cainkar 1988, 111-12). Upon arriving in a city like Chicago, chain immigrants could rely on the continued support of their extended families.

Alongside chain immigrants, however, a substantial population of "new peasant immigrants" settled within interstitial zones like Marquette Park on the city's Southwest Side. In doing so, they resumed the mediating minority role, buffering predominantly African American and white ethnic neighborhoods. These new immigrants also revived the older vocational patterns. They worked, for example, as peddlers, and then opened corner stores, gas station franchises, and other similar establishments (Cainkar 1988, 105). Others worked in the factories. A smaller third group, "autonomous immigrants" comprising mostly single men, studied in universities or vocational schools or worked in companies (Cainkar 1988, 110 and elsewhere; Cainkar 1998). Some of these individuals, including a participant in my research, started financial services enterprises, such as insurance and accounting offices (chapter 2).

The new peasants, mostly concentrated on the Southwest Side, came to outnumber the chain immigrants who had preceded them. Their new demographic dominance transformed the ethos of the immigrant community as a whole. Chain immigrants had held to the patriarchal code that constituted the rural social contract. But they considerably loosened their adherence to it as they moved to the suburbs - a process that began for this established group as early as the 1970s-and generally accommodated the mores of the wider US society, for example, by allowing women freedom to leave their homes to work and attend school. Autonomous immigrants vacillated in their adherence, with some upholding patriarchal village norms and others abandoning them entirely for the middle-class individualism of their workplaces. Possessing less access to economic resources and cultural prestige, the "new peasants" mobilized tradition and nationalism as markers of authenticity in the community. Against the chain immigrants, especially, they claimed to represent "true" Palestinian identity. Having arrived involuntarily in the United States, they insisted, like immigrants of earlier periods, that ultimately they would return home to the West Bank. In the interim, as an expression of this commitment to return and the nationalism it encoded, they sought to preserve the 'adat wa taqalid ("the customs and traditions") within their families and in the community at large. In this reinvigoration of tradition, they effectively "re-Palestinianized" the immigrant community (Cainkar 1988, 110-11 and 128).

This process of re-Palestinianization was gendered, occurring in and through the home. The women-wives, mothers, and daughters-of the new peasant immigrant group performed this labor. They did so, for example, by decorating 
their homes with artifacts (rugs, embroidered pillows, images of Jerusalem's Old City and the Dome of the Rock, Quranic inscriptions); preparing traditional cuisine; deferring to elders and to men; and guarding their sharaf, a woman's sexual honor, the markers of which were modesty and virginity. Modesty at this time did not entail wearing hijab scarves or jilbab coats, practices that would accompany the Islamic shift in the 1990s. Rather, women signaled it by caring for the home and avoiding being seen in the company of men unrelated to their families. Safeguarding sharaf in this way signaled commitment to the patriarchal and patrilocal ethos of village life and thereby to an "authentic" Palestinian identity. Community networks reinforced these norms, primarily through gossip. Occasionally, direct coercion came to bear when husbands ordered wives back to their villages or when, in rare instances, male members of a family resorted to physical violence (Cainkar 1988, 119-29, 147-48).

Men, by contrast, had license "to escape" into the wider US society to work, seek leisure in nightclubs, and pursue extramarital relationships (Cainkar 1988, 118, 122-24). This patriarchal double standard took a more stringent form in Chicago than it did in home villages, where women typically had more latitude to move independently beyond their homes (124). ${ }^{20}$ Cainkar (1988) attributed this phenomenon - the gendered double standard and the concomitant insistence on maintaining "tradition" - to a number of factors, including "statelessness, involuntary exile and strong attachment to the homeland, the hostility Palestinians face in the US, and above all, an ideology of exile that calls for cultural preservation" (126). Racism, especially, heightened defensiveness, rejection of the wider culture, and greater self-segregation within the home and enclave (129-33). ${ }^{21}$

Another likely explanation for re-traditionalization, however, one that Cainkar did not explore, was the sense of guilt that accompanied the immigrants' relationship to "back home." The relationship carried ambivalence. Those who left felt pressure to succeed and also to maintain fidelity to the culture and its values. When they returned to their communities, however, they might encounter accusations of having abandoned the ways and customs of "back home," of having "gone native," of having become "American." The desire, then, to be seen as retaining fidelity to the culture might have served as an impetus to maintain the home as a space of authenticity, that is, of tradition and patriarchal norms.

This concern to preserve authenticity registered in the observations of a participant in the research for this book, a man I had known for more than two decades, who came to Chicago in the early 1990s. He had been a political activist and member of the Palestinian Communist Party in the West Bank during the First Intifada. In our interview, he commented that the immigrant community seemed frozen in time, a relic of an era predating the 196os. Life had moved on "back home," he said. The Chicago diaspora, however, in its concern to preserve the past, had resisted change. My friend's assessment was not entirely accurate. The diaspora had in fact transformed Palestinian identity in very specific ways. Indeed, the very attempt 
to retain the past-or a traditionalized reconstruction of it-constituted one such transformation. This preservation effort was necessary so long as "return" to the confiscated homeland remained the defining collective aspiration.

\section{THE ASCENDANCY OF SECULAR NATIONALISM:}

$1967-1990$

The retraditionalization-"re-Palestinianization," in Cainkar's terms-that the "new peasant immigrants" spurred coincided with the rising prominence of nationalism in the immigrant community as a whole. This nationalism, which became pervasive through the creation of community organizations that aligned ideologically with Arab Nationalism and the Palestine Liberation Organization, emphasized "return" (al-awda) to Palestine and, symbolically, to its peasant past, from which the nation derived its territorial claim..$^{22}$ Figured primarily in terms of turath (heritage), the elements of this past-the checkered hatta scarf of Palestinian farmers, the embroidered dresses (thiyab) of village women, and village line dances (dabka) (Figure 6) - became symbols in a nationalist iconography displayed in Palestinian community spaces, gatherings, and public protests.

This symbolic array and its accompanying narrative of preservation reinforced patriarchal gender norms. In nationalist iconography, the land of Palestine frequently appeared as a woman whom the primarily male guerrilla fighters (fida'iyun, "fedayeen") and martyrs (shuhada'), situated in the exile, sought to liberate and revive by seeding her with their blood (Amireh 2003). Those communities that remained within Palestine also had a role, a feminized one, which entailed persisting physically and culturally in the land. The term sumud (steadfastness) entered the nationalist lexicon to describe this task for those who lived under Israel's military occupation. In tension with these terms, however, was the Marxist-inspired lexicon of revolution. "Tradition," in this perspective, was a regressive force impeding

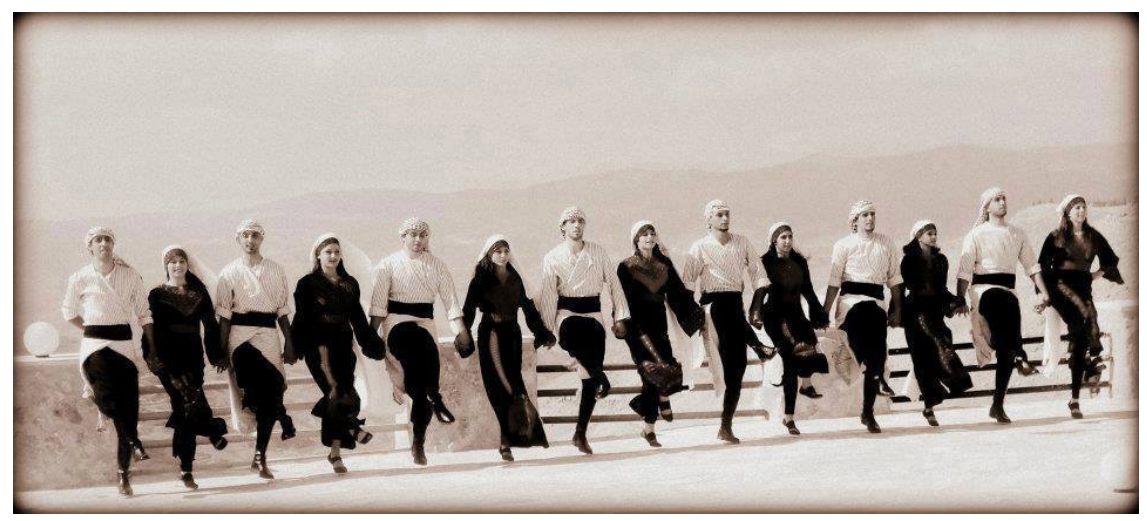

FIGURE 6. Palestinian dabka. Courtesy of Sarah Canbel. 
the liberation project. The "revolution," by contrast, emphasized the necessity to modernize women through education and mobilization in the struggle. The secular factions - for example, Fatah, the Popular Front for the Liberation of Palestine, the Democratic Front for the Liberation of Palestine, and the Communist Partyembraced this idea. They actively recruited women and provided avenues for their participation that served, albeit incompletely, to break the hold of traditional gender roles (Y. Sayigh 1997).

These currents-patriotic retraditionalization and revolutionary liberationcut crosswise in the Chicago community. For example, in the Southwest Side enclave, women remained bound to the home as site of their social honor and socially prescribed role, yet, they also encountered alternative avenues of validated activity within the new, nationalist community organizations. Groups such as the Union of Palestinian Women Associations (UPWA) mobilized immigrant women on the national question and also against patriarchal norms. Based at the Arab Community Center (the markaz) on West $63^{\text {rd }}$ Street, the UPWA accomplished these tasks through outreach to women in their homes as well as through conferences and workshops. The organization also forged public political roles for these women by bussing them to rallies and protests in the Loop (Cainkar 1988, 207-8). ${ }^{23}$

Post-1967 secular nationalism unified Palestinian identity across multiple sites of exile. It also linked Palestinians to the nonaligned Third World solidarity movement. Third Worldism connected US minorities to global anti-colonial independence struggles (Fischbach 2019; Pennock 2017; Feldman 2015). Locally, in Chicago, this form of activism manifested in alliances between immigrant rights and national liberation groups. The leaders of the Palestinian community organizations participated in these alliances, emphasizing the shared struggle for decolonization of the homeland and civil rights in the diaspora.

A particularly important event that cemented these links and mobilized them as a force in city politics was the 1983 campaign to elect Harold Washington, the first African American mayor of Chicago. Secular-left Palestinian leaders contributed financially to the campaign, which unified diverse minority constituencies, and staffed efforts to mobilize the vote in the immigrant community. A particularly important effect of this participation was the reorientation of the concerns of these leaders toward American domestic politics. These leaders had perceived voting as pointless, since the US government would never, in their view, change its policies toward Israel. Yet these same individuals increasingly saw the need to enter into cross-ethnic coalitions to gain support for the Palestinian cause locally and to gain access to city resources to support their community. The Washington campaign promised to divert funds away from the wealthy Loop and Near North areas to the working-class and poor neighborhoods to the west and south.

The Palestinians involved with the Washington coalition had arisen as community leaders within two main organizational contexts: Arab nationalist student groups and secular nationalist community organizations. The most prominent 
student formations included the Arab Students Association (ASA) and the General Union of Palestinian Students (GUPS). The ASA, which formed as an inter-Arab response to the war of 1967 , held seminars, distributed fliers, and hosted a film festival. It eventually split apart into rival factions and gave way, during the 1970s, to the GUPS. GUPS linked students in the diaspora to the Palestinian national struggle. It became the center of Palestinian student activism until the PLO's abeyance following the creation of the Palestinian National Authority in the mid-199os. Beyond the campuses, nationalist community organizations provided the principal mobilizing structures. These organizations aligned ideologically with the various PLO factions. The organizations coordinated with the university student groups. Students helped staff organization-led events. The organizations, for their part, offered post-graduation opportunities for students who wanted to continue their activism. ${ }^{24}$

\section{SUBURBAN TRANSITION AND THE RELIGIOUS TURN:}

\section{0-PRESENT}

Beginning in the mid-1980s the demographic and institutional center of Chicago's Palestinian community shifted yet again to the near southwestern suburbs, especially Bridgeview but also Oak Lawn, Tinley Park, Orland Park, and Palos Hills. Wealth accumulation, professionalization, and fears associated with gun and gang violence drove the transition. ${ }^{25}$ Some of my respondents expressed guilt about abandoning the urban enclave. They viewed Palestinian suburbanization, critically, as merely a replication of the migration of ethnic whites a generation earlier.

White suburbanization in Chicago intensified after the Second World War. Fueled partly by the GI bill, which sent thousands of returning veterans to universities, the postwar economic boom expanded the professional middle class, enabling more families to buy new homes beyond the urban core. The amplification of the racial border wars escalated this suburbanization process, which came to be known as "white flight." Of the 485 reported incidents of racial violence between 1945 and 1950, three-quarters pertained to "housing or property" (Abu-Lughod 1999, 222). More than 85 percent of the violence occurred on the edges of the Black Belt in response to attempts by African Americans to move into predominantly white urban neighborhoods (222). After 1948, when the United States Supreme Court ruled in Shelley v. Kraemer that restrictive covenants lacked legal enforceability, whites skittish about racial integration moved in large numbers to all-white suburbs. Seeking to profit from these conditions, real estate agents stoked panic sales and then resold the properties at inflated rates to black homebuyers. Whites lacking financial means to leave resorted to violent harassment of their new black neighbors in an effort to preserve racial exclusivity. Local and state government assisted the effort: despite the Shelley ruling, government agencies continued to enforce preexisting exclusionary covenants. The Federal Housing Authority, too, 
perpetuated "redlining" policies by insuring housing developments that had maintained racial exclusions (Hirsch 1983, 10-12; Abu-Lughod 1999, 222-23; Self 2003; Kruse 2005; Satter 2009; Rothstein 2017).

Exacerbating racial tensions, the federal Urban Redevelopment Act of 1949 mandated slum clearance and lot resale to private developers who had agreed to build homes for moderate-income people. In Chicago, most of the "slum" areas were in the Black Belt. The law required that residents who would lose their homes because of clearance be given new space in public housing. Siting these public works, however, led to new border wars, since the only available lots for such projects were toward the urban periphery near white areas. White outmigration intensified: between 1950 and 1970, the percentage of white non-Hispanics in Chicago's municipal boundaries plunged from approximately 86 percent to 65 percent (1999, 230-31, 331-32) ${ }^{26}$ As whites left, the border wars subsided. Residents in the historic Bronzeville area (within the Black Belt) moved into the vacated neighborhoods to the south and west. The West Side, however, continued to experience tensions as poor blacks and Puerto Ricans found themselves enclosed between the expanding Loop area-large tracts had been seized for the new University of Illinois campus in what is now the West Loop-and the majority white township of Cicero. The city-suburb divide had become a simultaneous class and racial bifurcation (Abu-Lughod 1999, 221-23, 230-233; Squires, et. al., 1987, 102-17).

Chicago's intensified socioeconomic and racial segregation hardened as the decades passed. By 1990, "less than 38 percent of the city's residents reported themselves 'white non-Hispanic,' and this category included many of the most recent immigrants from the Middle East, the Indian subcontinent, and lessdeveloped parts of Europe" (Abu-Lughod 1999, 331). In 1950, Chicago's "nonwhite" population stood at 14 percent. Ten years later, it had increased to one-quarter and within sixteen years it reached one-third of the city's population (230-31). By 1990, African Americans, specifically, who now accounted for 39 percent of the city's overall demographic concentration, outnumbered non-Hispanic whites ( 38 percent of the population). Hispanics-Puerto Ricans and Mexicans-contributed nearly 20 percent by that same year (334). The few suburbs housing non-white residents-including, increasingly, Arabs and $\mathrm{Muslims}^{27}$-were situated almost completely within Cook County, leaving the outer suburbs nearly entirely white (332). Those whites remaining in the city concentrated primarily along the lake north of the Loop and in zones abutting white suburbs at the city limits in the northwestern and southwestern sectors. African Americans tended to remain within an expanded "Black Belt" in the city's South Side; they also occupied the "second ghetto" on the West Side. Latinx (but also Palestinians) "occup[ied] "buffer zones' [ . . ] between these black and white sectors" (332). ${ }^{28}$ By 2010 , blacks and Hispanics/Latinx-32.9 percent and 28.9 percent, respectively-combined to outstrip non-Hispanic whites, now just 31.8 percent of the city's total population of 2.7 million (Mullen and Ortiz-Healy 2011). ${ }^{29}$ 
The sharp decline in heavy industry in the postwar period exacerbated the citysuburb divide. Unlike the "gunbelt" - the eastern, southern, and Southern California regions of the United States that hosted Cold War defense industries-Chicago and the Midwest, generally, never fully recovered from the Great Depression. Government demand for steel during the Second World War partly revitalized Chicago's manufacturing base, but structural adjustments-reallocation of federal investment to high-tech defense industries and relocation of steel and car production to southern states and abroad (for example, to Japan)_decimated working class livelihoods. Between 1967 and 1982, Chicago lost 250,000 (46 percent) of its manufacturing jobs (Abu-Lughod 1999, 323). The industries that remained in, or came to, the region located their plants and headquarters increasingly in the suburbs. Sharp losses also hit service-sector employment. Between 1991 and 1992, 31,000 service jobs disappeared in the city. The suburbs, meanwhile, added 19,000 service jobs during this same period (326). Still, Chicago retained its position as a node in the automated international finance network, principally through the Chicago Mercantile Exchange, known as "the Merc," which created a global marketplace for the buying and selling of commodity futures and options (derivatives). The expansion of the financial sector that the Merc fueled mostly benefited a small group of brokers downtown and in capitals abroad. Other than in the central business district, the Loop, it produced few jobs.

Taken together, these processes sharpened economic disparities. The predominantly white foreground-comprising the Loop and the Near North Side neighborhoods-gained in wealth as the non-white background to the west and south of the Loop became increasingly impoverished. Similar disparity marked the suburban-urban dichotomy. According to the 1980 census, the greater Chicago metropolitan area hosted twelve of the wealthiest communities in the nation but also ten of the sixteen poorest (Squires, et. al., 1987, 24, cited in Abu-Lughod 1999, 329). Unsurprisingly, according to a 1991 Urban League report, wealth gaps between Chicago's whites and blacks had increased far more rapidly than in other parts of the United States (Abu-Lughod 1999, 330).

The hollowing out of the urban neighborhoods that began with "white flight" continued in the near suburbs. Poverty increased accordingly in these urban areas, which had become centers of immigrant concentration, including for Palestinians, from the 1980s onward (Moser 2013). The factors driving "white flight" also propelled the Palestinian suburban shift. Imm 'Umar, mentioned earlier, explicitly identified racial factors in her account of her own family's residential shifts during the 1960 s and 1970s. She and her family moved multiple times whenever "the neighborhood would change." She described the segregation between African Americans and whites and how "when blacks would move in, then everyone would move out." Her own move into the suburbs, which occurred after her marriage, followed the trajectory of white communities into these same spaces beyond the urban core.

The movement of Palestinians to the near southwest suburbs pointed toward a broader phenomenon. As Latinx, South Asians, and Arabs, primarily, abandoned 
older immigrant centers within the urban core, they effectively "browned" the adjacent suburbs to which they moved. The "browning" concept challenges standard assimilation theory. Logan and Zhang (2010), for example, argue that rather than assimilation, what has occurred in the suburban transition of ethnic minorities is the "globalization of the suburbs" - that is, the diversification that occurs as minority groups move into previously all-white communities. Lubin (2008), in his exploration of the movement of Latinx into Berwyn, a historically white suburb, argues similarly that Latinx are not so much assimilating as they are "Latinizing" the suburbs. They are "browning" Berwyn, effectively altering its cultural characteristics and institutional forms.

\section{BROWNING BRIDGEVIEW: PALESTINIAN \\ SUBURBANIZATION AND THE NEW ISLAMIC MILIEU}

What the "browning" studies describe holds true as well for the nearby southwestern suburbs, such as Bridgeview, into which Palestinians have moved since the 1990s. Rather than assimilating, Palestinians have reconstituted their enclaves in these spaces, but in doing so they have also significantly reoriented the community ethos through the Islamic turn discussed in the introduction. This shift is relatively new, and its reasons for manifesting are complex.

One important factor in the reorientation has been the creation of the Mosque Foundation. ${ }^{30}$ This organization and the nearby businesses that cater to local consumer preferences have "Arabized" and "Islamized" - indeed globalized-the near southwest suburban expanse. Significantly, the enclave that has emerged continues to perform the mediating "stranger" role, effectively buffering white communities to the west from the now predominantly African American South Side urban space. As noted earlier, in moments of conflict in which Middle Easterners have figured as "enemies," the persisting "mediator" status has given way to a perception of a malevolent "other." ${ }^{31}$ Following the September 11 attacks, for example, white ethnics marched on the mosque in Bridgeview, unwittingly replicating previous "border war" tactics (Millar 2001; Terry and Ahmed-Ullah 2001).

The building of the Bridgeview mosque represented a significant advance in religious institutionalization. The mosques that existed prior to the construction of this new edifice were small urban storefronts that limited their services to providing a place for prayer and basic religious instruction. The shift to the suburbs marked a change in this ad-hoc institutional situation: desiring a stable meeting space, the first Palestinian migrants to the suburbs in the 1950 incorporated the Mosque Foundation and its annex organization, the American Arabian Ladies Society (AALS).

Imm 'Umar, mentioned previously, discussed the background of these developments. Her cousin was a founding member of the AALS and another distant cousin 
served as the mosque's first imam. The main impetus for the project, according to Imm 'Umar, was the war of 1967 . Islam, she said, had not been central "to our identities" at the wider community level up until this point. In the family, her parents did instill an awareness that they were Arabs and Palestinians and Muslims. Her father recited from the Quran when the family gathered for occasions in the home. After the war, however, the arrival of the new immigrants catalyzed a shift in collective awareness. These individuals "were activists" who began raising consciousness about the plight of Palestinians now living under direct Israeli military rule. The older, established immigrants also began to see that "we had no country to return to" and consequently there was a need to create institutions to sustain community life intergenerationally. Imm 'Umar described efforts to start language, history, and religion classes for youth. These activities occurred alongside the formal establishment of the Mosque Foundation as a community organization in "a storefront on $79^{\text {th }}$ Street, on the East Side." Along with the cultural programs, the new center hosted "welcome back [from Palestine] parties, engagements, and marriage parties." Eventually, enough money was collected to buy the plot of land that became the permanent site of the current Mosque Foundation in Bridgeview.

These developments represented a significant institutionalizing step. Prior to the creation of the Mosque Foundation, families relied on "Shaykh "Aroubi from Dearborn [Michigan] to perform burials and marriages." After the creation of the Mosque Foundation, the organization's leaders sought to appoint their own permanent imam. Imm 'Umar's cousin, a well-respected elder, volunteered for the position and was given certification through the Jordanian embassy in Washington, DC, and by the State of Illinois. He began officiating at marriages, divorces, and funerals. He also led the community's slow effort to raise money for a new structure on the land that had been purchased in Bridgeview. He remained in the position until the early 1980s. "[My cousin] wasn't degree smart; but he was very knowledgeable and was respected in the community for his honesty," Imm 'Umar recalled.

The choice of Imm 'Umar's relative to be the first imam reflected a crucial assimilating transition among the older immigrants in response to the impact of the war of 1967. This shift entailed a transformation of traditional leadership roles. Leadership in Palestinian villages typically centered on the role of older, respected men. These male elders selected a mukhtar-literally, "one who is chosen"-from among their ranks to represent village interests to outsiders and mediate disputes among insiders..$^{32}$ Often the mukhtar was the shaykh, the nominal religious head of the village. The shaykh, like the mukhtar, held his position by virtue of age and reputation but was known, as well, for basic religious knowledge. This individual did not always possess formal religious training attested, for example, by an ijaza-an authorization to teach and preach-from an established center of learning such as al-Azhar University. He was known, rather, for being a virtuous exemplar who perhaps could recite from the Quran and knew the formalities 
of the marriage contract and other basic rituals, including burial. Imm 'Umar's cousin was accorded the status of imam because he was seen to have these qualities. He was not "book smart" but was known to be morally upstanding and to possess more religious knowledge than other immigrant elders.

In the diaspora context of the United States, formal licensing requirements transformed this family elder into a figure-the clergyman-recognizable within the American cultural milieu. By incorporating a mosque and appointing a religious leader, Imm 'Umar's relatives and their community thus began to identify collectively as Muslims and in doing so were beginning a type of social integration that had typified the experience of many other immigrant groups in the United States. The "religious turn" indexed the assimilation of the community through the formation of religious organizations that served not only ritual needs but also the functions of community representation, support, education, and leisure in a manner similar to Catholic parishes, Protestant churches, and Jewish synagogues. In this process, the community was adapting Islamic institutions to American religious organizational forms, thereby facilitating their capacity to be recognized as part of US society (Riedel 2009; Kivisto 2014, 65-66).

Assimilation processes, however, were not the only forces at work. The war of 1967 created the conditions for the renewal of political Islamic tendencies even as secular nationalism became dominant in the immediate aftermath of the conflict. This renewal culminated in the formation of powerful Islamist organizations and an accompanying religious revitalization that challenged the hegemony of secular Arab nationalism in the Middle East. These processes also affected the Palestinian immigrant community in Chicago. The impact registered most directly in a struggle to control the Mosque Foundation board in the late 1970s. The roots of this struggle lay in the composition of the new immigrants who arrived after 1967.

During the 1970s into the mid-1980s, the new immigrants came to include not only the "new peasants" whom Cainkar (1988) documented but also professionals - doctors and engineers-who possessed extensive economic and transnational institutional resources. Some of these individuals were sympathetic to reformist movements like the Muslim Brotherhood..$^{33}$ As such, they were forerunners of the generational split between secular nationalist and political Islamic movements that would occur in Palestine during and after the First Intifada (1987-93).

A group of such individuals-Palestinian and other Arab immigrants who had established themselves in professional fields and lived in Bridgeview and other adjacent southwest suburban communities-began to organize an effort to take charge of the Mosque Foundation. The initiative to build a mosque on land purchased in Bridgeview in 1973 had stalled for lack of funding. Seeing a chance to revive the campaign, the founders of the mosque project, established immigrants who had arrived from Beitunia before 1967, initially welcomed the support of the new professionals. The newcomers raised $\$ 1.2$ million in total, with $\$ 369,000$ coming 
from private sources in Kuwait, \$152,000 from the government of Saudi Arabia, and $\$ 135,000$ from the United Arab Emirates Ministry of Religion (Ahmed-Ullah, et al., 2004; Cainkar 2004, 112). The established Beitunians, by contrast, had required twenty years to collect $\$ 50,000$ for the lot and likely would have required an equally long period to produce the funds for the mosque building itself.

Welcoming the assistance of the new professionals, however, had an unanticipated consequence: a shift of power and influence in the community. In 1978, promising to raise the necessary funds to build the mosque, the newcomers gained a majority on the Mosque Foundation board. By 1981, they had succeeded in procuring the funds and building the mosque. They then removed Imm 'Umar's cousin and installed in his place an imam who had received formal religious training and certification in the Middle East and who shared their reformist leanings.

Reformism emphasized the compatibility of Islam with the sober and rational ethos of modern middle-class professional life. This type of Islam emphasized textual orthopraxy: the Qur'an and Hadith were to be the sole authoritative determinants of faith. In this view, the traditional village piety of the established immigrants lacked foundation and consequently had allowed assimilation of nonIslamic practices. As one of the reformist leaders in Chicago put it: "We wanted to end un-Islamic practices like Easter egg hunts; [ . . . ] we wanted a real mosque, to raise the religious standard, and not just have a community center like the older group was thinking." The new imam installed by the reformers sought to achieve these goals through preaching, seminars, Qur'an lessons, youth education, and a range of other measures focusing especially on women's comportment. He instituted gender segregation and the requirement that women wear hijab scarves and modest clothing in the mosque, but also ideally at all times outside of the home. Through such practices, he and the board endeavored to align community identity with the reform orientation to which they were committed. ${ }^{34}$

The measures provoked backlash. Conflict erupted when a group of Beitunians surrounded the new board leadership in the mosque parking lot in November 1981. Bridgeview police were called to the scene to intervene. ${ }^{35}$ That same year, the AALS, which held the deed to the mosque's land, filed suit against the new Mosque Foundation board, which was seeking to transfer ownership of the mosque to the North American Islamic Trust (NAIT) (Ahmed-Ullah, Roe, and Cohen 2004). The AALS disputed the legitimacy of the board and sought to prevent the transfer, which they feared would end local community control. According to a leader who backed the reformists, the AALS allegedly received financial support and encouragement to pursue the legal action from activists who sympathized with the dominant secular nationalist faction, Fatah. These individuals, he told me, viewed the mosque leadership transition "as a Muslim Brotherhood takeover." This was a false perception, he said. The people involved in guiding the leadership change were simply "faithful Muslims trying to improve their community." 
Without the backing of the Fatah-oriented group, he alleged, the AALS would never have had the financial means to bring their suit. ${ }^{36}$

The AALS legal action ended in a mixed ruling. The plaintiffs retained ownership of the land on which the mosque was built but lost their challenge to the legality of the new mosque leadership and to the transfer of the mosque title. The court ruled that the transition in leadership on the board and the hiring of a new imam had occurred in a legitimate manner. The management of the Mosque Foundation would remain with the new professionals. As multiple individuals interviewed for this project indicated, this leadership transition was decisive in transforming the Mosque Foundation into the primary mechanism of the suburban reformist shift. ${ }^{37}$

Since its completion in 1981, the Mosque Foundation has become a wellestablished and expansive institution. Each Friday, it hosts two separate prayer services, one in Arabic, the other in English, which as many as 3,500 worshipers attend at a time. Having undergone a recent expansion and remodeling, the updated space features marble flooring, sage-colored "eco-friendly" carpeting, large LCD monitors in the overflow prayer areas, corporate-style conference rooms, and a bookstore with an array of classical Islamic texts, copies of the Qur'an, and children's literature addressing key practices like charity, tithing, and prayer. Mahogany-finished desks, tables, and bookcases and large-screen desktop computers furnish the offices of the mosque director (head imam) and assistant director (assistant imam). The mosque provides a range of programs: religious education; marriage and divorce counseling; conflict mediation; youth activities; a food pantry catering to a neighboring community of mostly poor whites living in prefabricated "trailer" homes; a "weekend school" for children; and the full range of ritual services. ${ }^{38}$ On any given night, the large parking lot fills with cars as community members attend various functions in the prayer spaces and halls. During the feast to celebrate the end of the Ramadan fast, the mosque rents the neighboring Toyota Park soccer stadium to host as many as 18,00o people for the prayer. The mosque also maintains an active social media presence: its Facebook and YouTube feeds regularly post videos of conversions, prayer services, and sermons as well as announcements of upcoming programs. ${ }^{39}$

A second mosque, the Islamic Community Center of Illinois (ICCI), has provided an important locus for a much smaller concentration of Palestinians on the city's Northwest Side (West Belmont Avenue and North Narragansett Street area). Established in 2001, the mosque offers ritual services as well as Sunday Arabic and Qur'an instruction, an evening school for children, and youth programs. It also sponsors a private academy catering to pre-K through eighth grade students. The imams at the ICCI participate in the wider Islamic religious networks in the city and appear frequently at Mosque Foundation and American Muslims for Palestine events (chapter 3 ). 


\section{EXPANDING THE ISLAMIC MILIEU:}

\section{ISLAMIC EDUCATION}

The Islamic shift that has occurred since the 1980s has resulted not only from the reorienting of the Mosque Foundation toward a text-centered reformism but also from the establishment of two private Islamic schools on land adjacent to the mosque. Under separate administrations, the schools function alongside the mosque as the institutional anchor of the Arab-Palestinian and Muslim enclave in the southwest suburbs. The first, Aqsa School, takes its name from the al-Aqsa Mosque in Jerusalem's Old City. The school began in the Mosque Foundation basement in 1986 with seventeen students. Enrollment, limited to girls in grades six to twelve, jumped to eighty-five in the following year. In 1991, the board, under the leadership of three Palestinian professionals (two engineers and a physician), oversaw the purchase of land across from the Mosque Foundation for the school's current premises (completed in 1997). The new school offered instruction for pre-K through twelfth grade. Education was co-ed until the third grade; grades four to twelve remained entirely girls. Since the expansion, enrollment has averaged three hundred students per year. Ninety percent of these students have been Palestinian; nearly half have had Beitunian roots (Riedel 2009, 81-86).

The original rationale of Aqsa School was to create a separated space within which the "maturing daughters" of the community might be raised within an Islamic ethos and shielded from compromising moral influences in wider US society. One participant in my research illustrated how this mission manifested in the curriculum as she described her younger sister's experience at the school. The religion classes, she told me, required her sister and her classmates to read a book titled The Ideal Muslimah (Hashimi 1998). Her sister "hated this book" and refused to read it, and consequently religion was the only class in which she apparently did not excel. The book described the ideal Muslim woman as obedient to her husband and willing to create an environment of peace for him at home. It focused on the meaning of the Qur'anic term qawwamun, which appeared to establish the authority of men over women (Q4:34). It also featured a long section on the duties and responsibilities of men toward their wives. ${ }^{40}$

At the same time, Aqsa's general curriculum and extracurricular activities undermine the patriarchal messaging of the religion classes. Teaching in the other subjects focuses on preparing girls for college and careers. While the school's early graduates were often the first in their families to go to college, during the last three decades economic and social changes within the community have led to a growing emphasis on education. Today, most Aqsa School graduates go on to earn a bachelor's degree, and many also pursue graduate degrees or advanced professional training. Also, the religious instruction at Aqsa instills knowledge of the core texts that some girls then use to contest the patriarchal norms of their families, which they view as reflecting "culture" and not "religion." ${ }^{41}$ 
The second Islamic school, Universal School, lies across the parking lot from Aqsa School. Universal offers classes ranging from pre-K to twelve. The school is co-educational with gender segregation after the fifth grade. Universal is larger and more ethnically diverse than Aqsa. The school averages an enrollment of more than six hundred students per year and its staff comprises nearly fifty fulltime teachers. Predominantly Arab (Palestinian and Syrian, mostly) in composition, Universal's student population also includes South Asians, Africans, African Americans, and a handful of Latinx and whites.

Just as with the Aqsa School, the creation of the Universal school reflected the rising power and influence of the new professional class. The school began, for example, after the son of a Syrian immigrant physician reportedly saw pornographic images in the locker room of the public school that he was attending. Shocked by his son's account, the father organized other professionals within the Mosque Foundation community to raise money for a new school that would instill an Islamic orientation and shelter their children from corrupting influences in US society. The professionals activated the same international networks they had used to raise money for the mosque during the late 1970 and early 1980s. Within a matter of months, in 1988, they had secured enough funding to begin construction of the school on a plot of land adjacent to the mosque. The school opened two years later with 140 students and eleven teachers. A founding member of the Council of Islamic Organizations in Chicago and the Council of Islamic Schools in North America, the institution has become one of the largest Islamic schools in the United States (Riedel 2009, 82-86). ${ }^{42}$

A crucial difference separates the Universal and Aqsa schools. This difference reflects the ideological divide that first manifested in the struggle to control the Mosque Foundation. The Universal School embraces the Mosque Foundation's reformist Islamic program and emphasizes a broad, interethnic Islamic identity. It aims to be "universal" in the all-encompassing Islamic sense of "umma," or community. Aqsa School, by contrast, has drawn from mostly Palestinian families, many of whom initially resisted the reformist shift. ${ }^{43}$ Despite centering Islam as a core identity, this group retains a focus on Palestinian national concerns. The choice to name the school after the Umayyad-era mosque situated on the Haram al-Sharif in Jerusalem is indicative of this nationalist orientation. This mosque (al-Aqsa), along with the Dome of the Rock, is the preeminent symbol of the Palestinian claim to the Holy City and to Palestine as a whole. In its choice of name, thus, the Aqsa School links Palestinian cultural and religious identities. ${ }^{44}$

The Aqsa and Universal schools, along with the mosque, anchor the broader immigrant enclave in which they are situated. The subdivision surrounding the mosque features single-family homes with two-car garages, late-model Toyota Camrys and Honda Civics, neatly manicured mid-sized lawns, and recently planted tree saplings that have yet to afford much shade against summer heat and 
humidity. The owners of these homes are predominantly Palestinians and other Muslim families who came to the neighborhood after non-Muslim families began to vacate the area. In 2009, the mosque leadership claimed that two-thirds of those who regularly participated in its ritual services and programs lived in Bridgeview and its neighboring communities, compared to only one-third in 1999 (Livezey 2000, 176; Riedel 2009, 81).

The main shopping districts and industrial zones in the Bridgeview-anchored enclave feature Arab-owned shops and enterprises. Almost every one of these business establishments combines Islamic religious and nationalist symbolic displays. The Facebook page of a popular restaurant, Al Bawadi Grill on W. $87^{\text {th }}$ Street in Bridgeview, for example, not only advertises the menu but also publicizes calls to rally for protests and demonstrations in the Loop. Its Facebook site has featured photographs of the annual 'Id al-Fitr prayers at Toyota Park in Bridgeview. As well, Islamic and nationalist iconography appears in the restaurant itself, where photographs of the Dome of the Rock in Jerusalem's Old City and framed Qur'anic passages hang from the walls. These images juxtapose with the generic "Arab" sensibility of the Bedouin textiles above the booths and tables, the Arab pop music, the satellite feed from the Al Jazeera TV station, and the mix of Arabic and English conversation of the patrons. Arab Christians also come to the restaurant because of the quality of the food and because of the Levantine ambiance.

\section{THE CHRISTIAN MILIEU: KEY STRUCTURES}

Palestinian Christian families live in the southwest suburban stretches, too, congregating socially in certain informally designated spaces, such as a Starbucks coffee shop on one of the main thoroughfares. Christians own businesses-insurance, legal services, accounting - in these neighborhoods. These businesses provide one of the few points of social intersection with Palestinian Muslims. For the most part, Palestinian Christians, like Muslims, remain segregated within their own sub-milieu, interacting socially within their families, churches, and predominantly Christian organizations such as the Ramallah Club. Dispersed in an arc sweeping from the north side of the city to the northwest suburbs (for example, Northlake, IL) down to the southwest suburbs, Christians lack a single point of residential concentration. Consequently, they typically drive long distances on the expressways to attend community functions.

Three churches serve as primary community anchors. St. George, mentioned earlier, became established slowly in a manner similar to the Mosque Foundation as a response to the communal and liturgical-ritual needs of a growing Orthodox community after 1967. The purchase of a former Korean Presbyterian church building in Cicero in 1984 positioned the community for growth: Cicero is centrally located between the northwestern and southwestern suburbs in which parishioners live. 
Today St. George counts approximately 1,500 mostly Palestinian families in its membership. The church has become a pilgrimage site because of its purportedly weeping icon of the Virgin Mary (Theotokos). This icon was first seen to weep in 1994. Older parishioners still recall the event with amazement. That same year, the Antiochian Orthodox Christian Archdiocese of North America declared the icon the "Miraculous Icon of Our Lady of Cicero." Cicero's town council has since declared the street in front of the church "Our Lady of Cicero Court" (Hanania 2015).

Leadership of St. George originally oscillated between priests of Arab and European ethnicity. From 1985 until the conclusion of my fieldwork, however, the church remained under the control of Fr. Nicholas Dahdal. Dahdal, a Palestinian, frequently represented St. George and, by extension, Palestinian Christians as a whole, at meetings that community activists called in periods of political crisis in the Middle East.

Like the Mosque Foundation, the church's liturgical services mix Arabic and English. But, whereas the Mosque Foundation provides separate English and Arabic prayer times, St. George combines the languages into its single Sunday morning liturgy, which can last for two hours or more. The church bulletin also appears in side-by-side Arabic and English scripts. The church provides a range of activities for children, teenagers, and young adults. One of its lay parish leaders has also created a bookstore featuring a sophisticated selection of theological, historical, and ethnographic studies on Orthodoxy and Orthodox religious communities globally. This individual, a Jordanian immigrant, also sponsors occasional lectures by authors in the church's basement community hall. In November 2014, for example, he invited Fr. Sidney H. Griffith of the Catholic University of America to speak about his recent book on the Arabic Bible (Griffith 2013).

Two other churches also draw Palestinian Christian membership. These include St. John the Baptist Melkite Catholic Church, described earlier, in the northwest suburb of Northlake, and St. Mary Antiochian Orthodox Church in the southwest suburb of Palos Hills. Established in 1969, but having origins in late nineteenth century Lebanese immigrant groups, St. John caters to Melkites and Roman Catholics and features Sunday liturgies in Spanish, Arabic, and English. Membership is predominantly Lebanese, Syrian, and Palestinian. Like St. George, the church's bulletin appears in Arabic and English. St. Mary's is a bilingual, primarily Jordanian congregation with some Palestinian members. It began in 2003 to accommodate Arab Orthodox families that had moved into the far southwest suburbs. In 2011, the church purchased a 42,00o-square-foot property to house the congregation.

\section{CONCLUSION: MAHJAR SPACES}

The secular and religious milieus that have come to structure the social and political spaces of the Palestinian immigrant mahjar in Chicago have been and remain shifting zones within which diverse narrative trajectories-different "stories so 
far"- have intersected. These trajectories, religious and secular, have shaped individual immigrant subjectivities in multiple ways. As I show in the chapters ahead, individuals move through and across secular and religious space, engaging in a range of negotiations and reconfigurations of belonging. These journeys bear the traces of passage through and between other kinds of zones, too. Palestinian immigrant spaces emerge along the boundaries of Chicago's bifurcations: frontstage glittering city/backstage gritty city; white ethnic neighborhoods/the AfricanAmerican "black belt"; white far suburbs/black and brown inner city and near suburbs. The immigrant space introduces a bifurcation of its own, transnational in character, between amrika and the iblad (back home). And within these many spatial-temporal polarities, race, class, generation, and gender intersect. These intersections add additional complexity to the negotiations of identity within and across the secular and religious space of Palestinian Chicago.

The next chapter offers an in-depth analysis of the secular milieu and the stories that intersect and shift therein. Despite a prolonged moment of attenuation, secularism has not entirely disappeared. Its traditions persist intergenerationally within its remaining organizational spaces. These spaces are no longer predominant in the immigrant community. But they constitute zones in which an alternative nonsectarian mode of communal-national belonging continues to exist. Secularism also re-emerges in new forms-ironically, as later chapters will show, in response to experiences of disenchantment within the Islamized suburban milieu. 